\title{
Transition to virtual education at University of San Carlos of Guatemala 2020
}

\section{Mario Ramírez ${ }^{1}$, Olga Ruiz ${ }^{2}$}

${ }^{1}$ Dirección de Investigación, Facultad de Arquitectura, Universidad de San Carlos de Guatemala, Guatemala, ${ }^{2}$ Departamento de Investigación Educativa, División de Desarrollo Académico, Dirección General de Docencia, Universidad de San Carlos de Guatemala, Guatemala.

\begin{abstract}
The transition from traditional teaching to virtual teaching in public institutions of higher education (PIHE) is a process that began with the first computers in the 20th century, which has been accelerated by the Covid 19 pandemic, forcing the PIHE to adopt new virtual learning environments for which the traditional educational model was not designed at the University of San Carlos de Guatemala (USAC).

The global characteristics of the Covid 19 pandemic have affected USAC teachers, students, administrative and service workers, and authorities, who had to adapt various methodologies with the support of ICT to continue the educational process. The implementation and use of these technologies evidenced a digital divide both in cognitive processes and in the use and access of digital tools. The study addressed the trends of use and access to technology in three case studies at the campus of USAC in Guatemala City: Architecture, Humanities and Economic Sciences, with a sample of 2,128 students, who responded through a Google form survey instrument, interviews and a forum, from February to may 2020.

The results show that the different socioeconomic levels affect the access and use of technology for the educational process, which is why it is necessary for PIHE to adopt policies and strategies that guarantee education.
\end{abstract}

Keywords: Educative model; digital breach; digital devices; social and academic networks. 


\section{Introduction}

The transition from face-to-face modality to virtual learning environments in public institutions of Higher Education (PIHE) has been accelerated throughout 2020 due to the policies of physical distancing derived from the Covid 19 pandemic, which caused both teachers and students to change abruptly the dynamics of the educational process, which came to depend almost exclusively on digital platforms, which promised to be an efficient and effective solution to overcome physical barriers and fulfill academic programs, supported by the notion that groups of digital natives and immigrants, were supposed to dominate ICT (Prensky, 2001). However, such assumption was supported by Prensky's experience in the United States context, (Koustropoulos, 2011), within a generational theory such as Millenials, developed by sociologists Neil Howe and Willian Strauss (2009) in The Fourth Turning (Strauss \& Howe, 1997).

Nevertheless, reality showed that in Guatemala both teachers and students and the institutions themselves were not prepared to face a completely virtual modality, nor did they master ICT, showing, that instead of digital natives, as proposed by Van Dijk, there is a digital divide (van Dijk, 2006) this concept divides those who can possess technology and those who cannot, those who are skilled at taking advantage of it and those who are not as well as the development of new taxonomies applied to education (Bloom et al., 1956; Churches, 2009; Marzano \& Kendall, 2006).

Moreover, the lack of interaction between students and teachers, and between the students themselves, leads to emotional and physical disorders (Kennedy et al., 2009), in addition teachers show stress and the "lack of social-emotial competencies to cope with the circumstances" (van der Spoel et al., 2020, p. 624), among other problems, related to the adoption of technology by teachers in such a short time.

Other studies (van der Spoel et al., 2020; Almazova et al., 2020) have addressed the perceptions and experiences of teachers regarding the impact that the use of ICT has had in public higher education institutions that enable the Equity in access to technology for all, however, this research addresses trends in the use of ICT in three groups of students in three different academic units of the USAC, who have greater limitations than teachers, in access to technology such as Internet access, equipment, software, overcrowding, electricity, among others (Toro González, 2020; Pedró, 2020), a situation evidenced and aggravated by the Covid-19 pandemic.

\subsection{The traditional educational model}

At USAC, throughout the 20th century, the traditional teaching model has been used. "The most used throughout history, part of the principle that teaching is to transmit knowledge, which is possessed by the educator. In this model, the student occupies a passive role, he is 
a mere receiver of the knowledge that the educator must pour on him. In this sense, the educator occupies the leading role, since he must find a way for the students to learn, as if everything depended on him ". (Brockbank, 2017). This model, centered on the professor or teacher, in a traditional, face-to-face classroom environment, began to change with the process of self-evaluation of careers and programs of the USAC, in the nineties, with the appearance of digitization initiatives of the library catalog USAC headquarters, as well as the catalog of studies for remote online access. Later, in the second decade of the 21 st century, some academic units established virtual platforms, among which we can mention Moodle, Adobe Connect, Chamilo, among others. However, its use was limited to academic administration, and, to a lesser extent, some academic units used it for teaching. This changed in the context of the Covid 19 pandemic, in which there was an increase in the use of accademic platforms, as well as specific applications such as Meet or Zoom, that were rarely used before.

The change in the trend of ICT use began much earlier, with the so-called knowledge society, whose implications go beyond the mere use of technology and encompass socio-economic aspects at a global and local level. This is reflected in the access to digital tools used by students, in a society where the consumption of both goods and services, and ideas prevails in a dematerialized world immersed in dataism (Han, 2019), in the 4th industrial revolution, where economic and cultural dimensions and contexts that affect the educational, among which the transition from a sequential process to a multitasking environment can be highlighted.

\section{Method}

The central categories proposed by Mark Prensky (2001) relative to the educational process and his later self-criticism were identified, as well as other authors such as Susana Lluna and her collaborators (Lluna Beltrán \& Pedreira Garcia, 2017), Robert Darnton (2010), Marc Bloch (1993), among others, with which a Google Forms digital survey instrument was built. The survey included seven parameters: General Aspects; Technological aspect; Digital tools and traditional methods in data management; Multitask; Reading habits; Socio-economic aspects; and finally, Cognitive aspects. There were 37 questions, both open and on Likert scales. Prior to the development of the survey, the instrument was validated with a pilot study sample of 75 students from the Faculty of Architecture during 2019, after which, in 2020, information was adapted according to the specific disciplinary field of the three selected USAC academic units: Architecture, Economic Sciences and Humanities, with the participation of a sample of 2,189 students. The method included an on line survey, for the first six cathegories, and interviews, Atlas.ti, and a Zoom forum developed during may 2020, with the participation of 8 universities both from America and Europe for the Cognitive aspect. 


\section{Results}

\subsection{General aspects}

The structure of the population $(\mathrm{N})$ pyramids of the three academic units by five-year age groups, was analyzed, with data from the office of the registrar of USAC (Departamento de Registro y Estadística). This structure was then correlated with the sample, which shows similar composition, in terms of age groups and sex in the three academic units analyzed.

The survey reveals that most students $(71 \%)$ at the main campus of USAC, located in Guatemala City, come from the metropolitan area, even though, USAC has other campuses distributed in the country side of Guatemala.

\subsection{Technological aspect.}

Based on the hypotheses of Mark Prensky (2001), regarding the impact of technology, a series of questions were developed, with respect to the age at which students were born, the age when they had they first computer, their first cell phone, the first access to internet, among other aspects. It was found that about $80 \%$ of the students had access to a computer before the age of 14 , as can be seen in figure 1 .

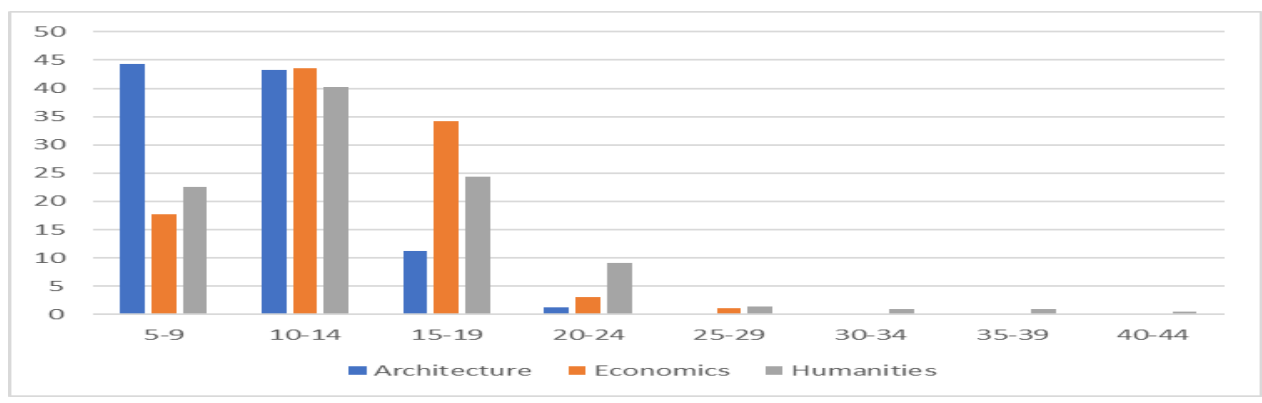

Figure 1. Relative frequency of the age at which the students who answered the surveys had access to their first computer, according to five-year groups in the three study units, indicated as a percentage. Source: Survey applied from February 25 to August 31, 2020, by the project team The myth of digital natives, trends in higher education. Using Google Forms, email and the dissemination platform of each academic unit.

\subsection{Digital tools and traditional methods in data management}

The questionnaire explored trends in the use of technology by asking students what do they do online? The specific questions regarding the trends in each academic unit fall outside the scope of this paper, however, the results indicate that in the three case studies, more than $60 \%$ of the time online is distributed between music and video, searching for information, email, watching the news (figure 2a, 2b, 2c). Followed by more than $30 \%$ dedicated to games, downloading books or applications, among others. Although the result confirms international trends in the use of social networks such as Facebook or WhatsApp, it also 
reveals applications with upward trends such as Instagram, Pinterest, YouTube, among others.
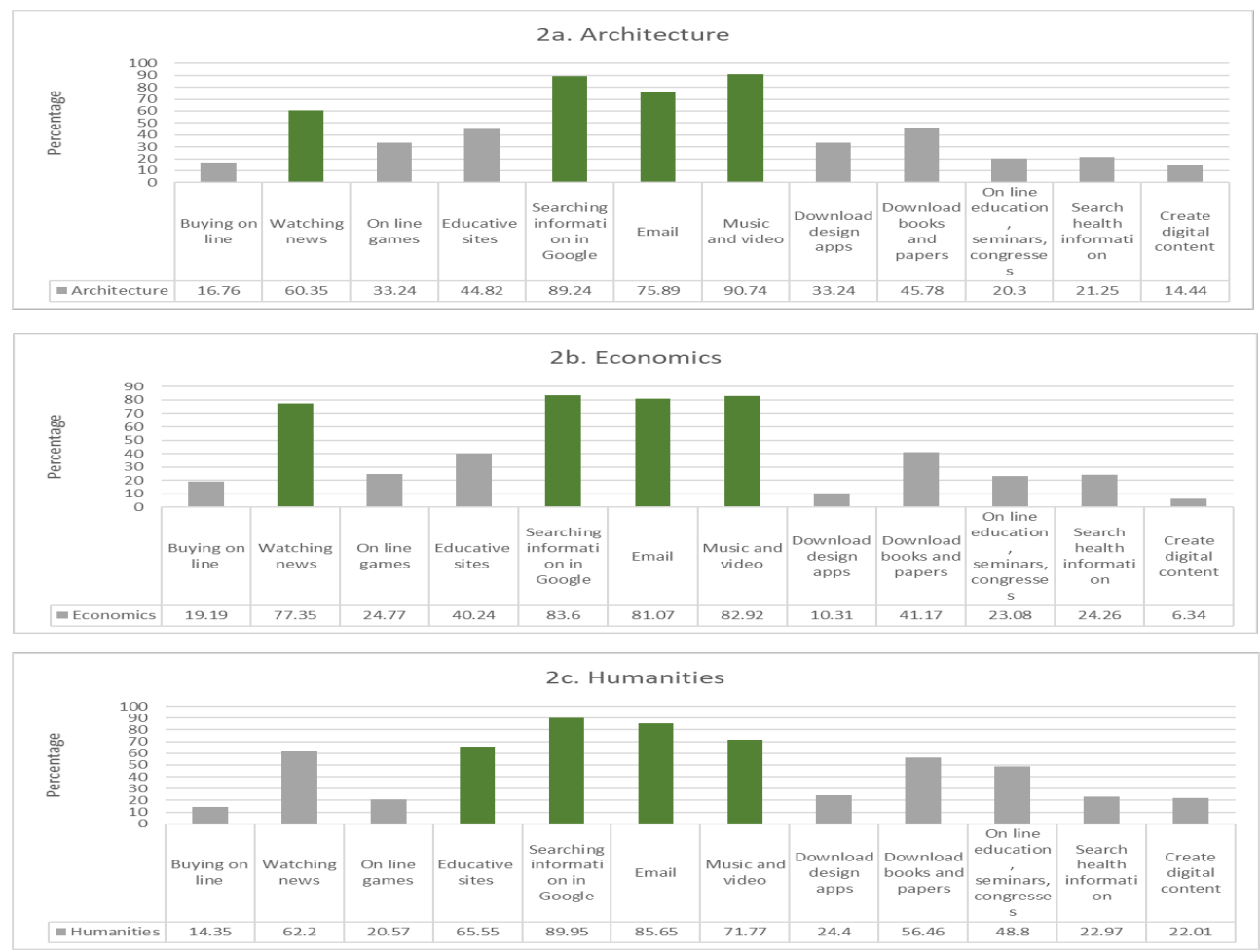

Figure 2a, 2b, 2c Relative frequency, of the activities that students do online, in the three study units. From top to bottom, 2a, Architecture; $2 b$ Economics; 2c Humanities. Source: Survey applied from February 25 to August 31 , 2020, by the project team The myth of digital natives, trends in higher education. Using Google Forms, email and the dissemination platform of each academic unit.

\subsection{Multitask}

This is a central and contradictory cathegory proposed by Prensky (2001). Even though students have the general idea that it is going to be required at work, and they feel capable of doing various things at the same time, with at least three applications on their computer, more than $44 \%$ indicate that they concentrate better when performing a single task at a time, and that they make more errors as a result of multitasking.

\subsection{Reading habits}

This group of questions explored first how students interact with the on line catalog of university libraries, and then, if they have access to academic contents available at other sources. Surprisingly, near $35 \%$ of students never consult the on line catalog. 


\subsection{Socio-economic aspects}

The socioeconomic aspects reveal that there are differences between the academic units, while in architecture $68.12 \%$ of students sustain their studies with family support, and $31.38 \%$ work to sustain their studies; In economics, this trend is reversed, since $80.13 \%$ work to sustain their studies, with only $19.70 \%$ dependent on family support. The case of Humanities falls between these two extremes, with $76.07 \%$ of working students and $23.92 \%$ of students with family support (figure 3).

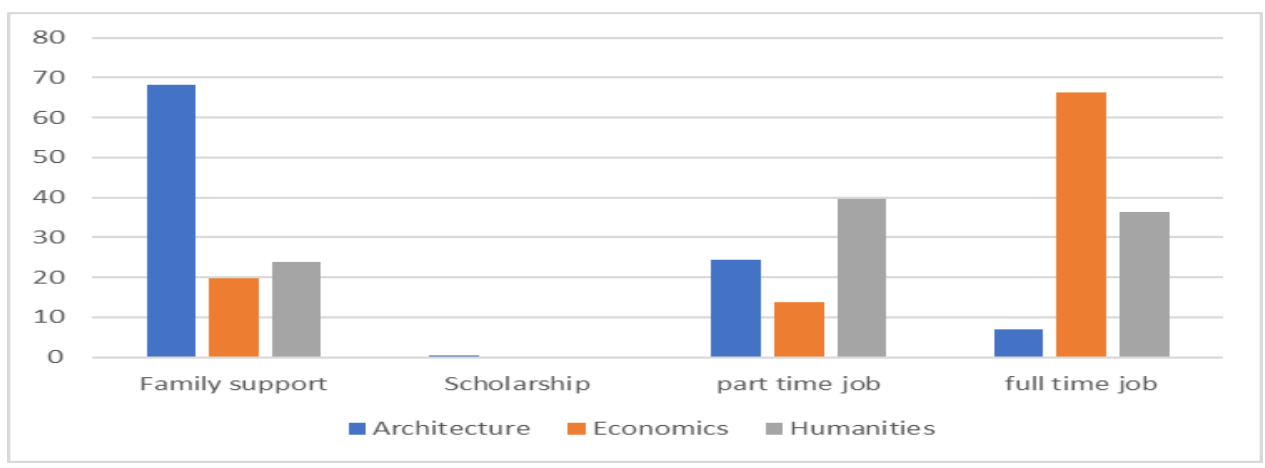

Figure 3 Relative frequency, indicated in percentage, of how students from the three academic units sustain their studies Source: Survey applied from February 25 to August 31, 2020, by the project team The myth of digital natives, trends in higher education. Using Google Forms, email and the dissemination platform of each academic unit.

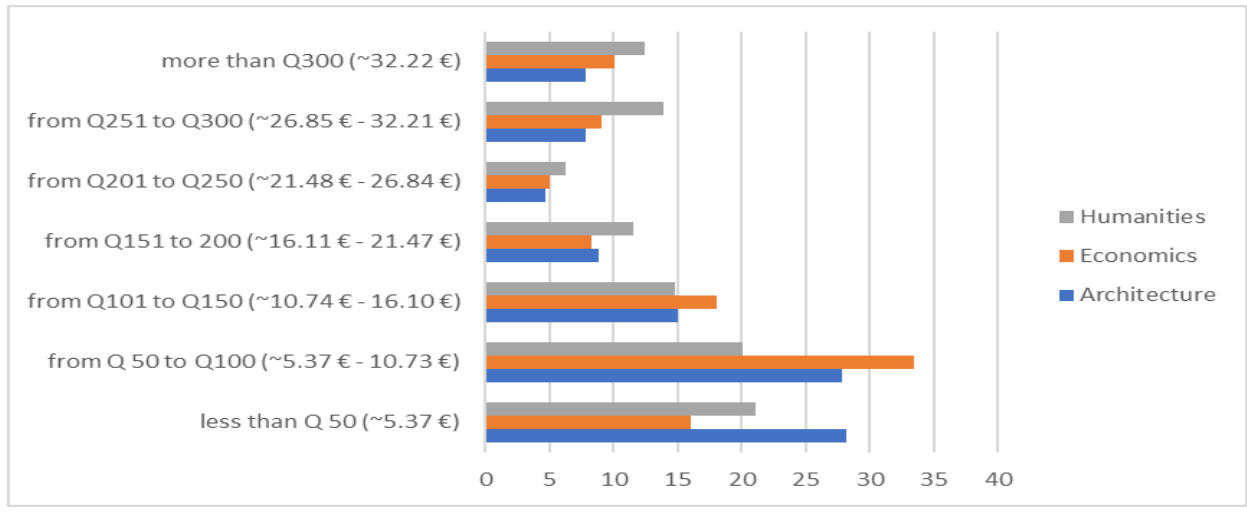

Figure 4 Relative frequency, indicated as a percentage, of how much the students of the three academic units invest in cell phone service each month trends in higher education. Using Google Forms, email and the dissemination platform of each academic unit. Source: Survey applied from February 25 to August 31, 2020, by the project team The myth of digital natives,

\subsection{Cognitive aspect}

The cognitive aspect were analyzed with Atlas.ti, interviews to students and teachers, and a zoom forum developed during may 2020, with the participation of 8 universities both from America and from Europe. Students think that there is a positive impact of ICT on their 
academic formation, however, they don't use ICT for academic purposes, and are devoted more to a superficial use of ICT through social networks, without an in depth critical thinking. Other aspects have been accelerated and made visible from the pandemic: first, educational and family activities are mixed together, there is a lack of eye contact among students and teachers, teachers lack interaction with their colleagues during evaluation, there is also according to Prof. Francesca Giofré, from Sapienza di Roma, a lack of technical vocabulary that has had to be constructed during the pandemic.

\section{Discussion}

The results show, first, the limits of the digital navites paradigm as proposed by Prensky, the supposed mastery of ICT by groups of students was only a myth. The idea of multitasking shows the pressure of the environment, that pushes students to declare on one hand that they are multitaskers, and on the other hand affirm that they concentrate better doing a single activity. Within the concept of Multitasking, the relationship of human beings with technology is hidden, in which human memory processes, with their limitations, can be increased with the use of digital devices where technology is used as a prosthesis. The immediate consequence is dependence on such devices and applications.

The transition from face-to-face classes to virtual learning environments already existed, and has been accelerated by the pandemic. This transition is reflected in the students' preferences in terms of using traditional media or digital tools to carry out their tasks, however, at the same time, as shown on table 6 , their access to internet data is limited by their budget, increasing the digital divide, which is also discipline sensitive, as shown in the table 5, differences between Architecture and Economics regarding family support or if students have to work to finance their studies.

In the case of Architecture, Economics and Humanities, this transition shows two polarized groups, those who use and those who do not use digital tools. The transition process has revealed the great digital divide in the USAC, and its socioeconomic implications for students in the context of the covid-19 pandemic, and also, the fragile support to public higher education institutions in Guatemala.

\section{References}

Almazova, N., Krylova, E., Rubtsova, A., \& Odinokaya, M. (2020). Challenges and Opportunities for Russian Higher Education amid COVID-19: Teachers' Perspective. Education Sciences, 10(368). https://doi.org/doi:10.3390/educsci10120368

Bloch, M. (1993). Apologia para la historia o el oficio del historiador (segunda ed). Fondo de Cultura Económica.

Bloom, B. S., Englehard, M. D., Furst, E. J., Hill, W. H., \& Krathwohl, D. R. (1956). 
Taxonomy of Educational Objectives: The Classification of Educational Goals: Handbook I Cognitive Domain. New York, 16, 207. https://doi.org/10.1300/J104v03n01_03

Churches, A. (2009). Edorigami. Bloom's Digital Taxonomy. https://edorigami.wikispaces.com/file/view/bloom\%27s Digital taxonomy v3.01.pdf/65720266/bloom\%27s Digital taxonomy v3.01.pdf

Darnton, R. (2010). Las razones del libro: Futuro, presente y pasado. Trama Editorial, S.L. https://books.google.com.gt/books?id=ufzZY6342gcC

Han, B.-C. (2019). Hiperculturalidad (F. Gaillour (trad.); primera ed). Herder.

Howe, N., \& Strauss, W. (2009). Millennials Rising: The Next Great Generation. Knopf Doubleday Publishing Group. https://books.google.com.gt/books?id=To_Eu9HCNqIC

Kennedy, G., Dalgarno, B., Bennett, S., Gray, K., Waycott, J., Judd, T., Bishop, A., Maton, K., Krause, K.-L., \& Chang, R. (2009). Educating the net generation. Australian Learning $\&$ teaching council.

Koustropoulos, A. (2011). Digital Natives: Ten Years After. MERLOT Journal of Online Learning and Teaching, 7(4), 525-539.

Lluna Beltrán, S., \& Pedreira Garcia, J. (2017). Los nativos digitales no existen : cómo educar a tus hijos para un mundo digital. Ediciones Deusto. https://books.google.com.gt/books?id=H8TjnAAACAAJ

Marzano, R. J., \& Kendall, J. S. (2006). The New Taxonomy of Educational Objectives. SAGE Publications. https://books.google.com.gt/books?id=JT4KAgAAQBAJ

Pedró, F. (2020). Covid-19 y educación superior en América Latina y el Caribe: efectos, impactos y recomendaciones políticas. En Análisis Carolina. Fundación Carolina. https://doi.org/10.33960/AC_36.2020

Prensky, M. (2001). Digital Natives, Digital Immigrants. On the Horizon, 9(5).

Strauss, W., \& Howe, N. (1997). The Fourth Turning: An American Prophecy. Broadway Books. https://books.google.com.gt/books?id=c92-60DlXOUC

Toro González, D. (2020). Educación Superior en Latinoamérica en una economía postcovid. Revista de educación superior en América Latina, 8(Monográfico), 45-52.

van der Spoel, I., Noroozi, O., Schuurink, E., \& van Ginkel, S. (2020). Teacher's online teaching expectations and experiences during the Covid19 pandemic in the Netherlands. European Journal of Teacher Education, 43(4), 623-638. https://doi.org/https://doi.org/10.1080/02619768.2020.1821185

van Dijk, J. A. G. M. (2006). Digital divide research, achievements and shortcomings. Poetics, 34, 221-235. 